\title{
Variation in the diets of hydrothermal vent gastropods
}

\author{
Breea Govenar $^{\mathrm{a}, \mathrm{b}, \mathrm{c}}$, Charles R. Fisher ${ }^{\mathrm{b}}$, Timothy M. Shank ${ }^{\mathrm{c}}$ \\ ${ }^{a}$ Biology Department, Rhode Island College, Providence RI 02906 \\ ${ }^{\mathrm{b}}$ Department of Biology, Pennsylvania State University, University Park, PA 16801 \\ ${ }^{c}$ Department of Biology, Woods Hole Oceanographic Institution, Woods Hole, MA 02543
}

Corresponding author:

Breea Govenar

Biology Department

Rhode Island College

Providence, RI 02908-1991

Tel: (401) 456-9631

Fax: (401) 456-9620

E-mail:bgovenar@ric.edu

(C) 2015. This manuscript version is made available under the Elsevier user license 


\section{ABSTRACT}

A prevailing paradigm of hydrothermal vent ecology is that primary consumers feed on chemoautotrophic bacteria. However, for the purposes of reconstructing vent food webs and for following energy flow from the generation of rock and fluid chemistry to primary and secondary productivity and consumption that extends to the overlying water column, it remains unclear which consumers feed on which bacteria.

Through paired analyses of carbon and nitrogen tissue stable isotope values with unique 16S rRNA sequences from the stomach contents, we determined that two species of gastropod grazers appear to feed on epsilon-proteobacteria, while two other species have more diverse diets, including one species that consumes alpha-proteobacteria, planctomycetes, and non-green sulfur bacteria. Different carbon fixation pathways used by epsilon- and alpha-proteobacteria may account for the variation in the carbon stable isotope values among the consumers. Furthermore, our results indicate that trophic specialization and niche partitioning may contribute to the distribution and abundance of vent-endemic gastropods and support the hypothesis that consumers in the warmer habitats feed on epsilon-proteobacteria that use the rTCA cycle, while in the cooler habitats they feed on other bacteria that use the CBB cycle. These results suggest that the phylogenetic and metabolic diversity of free-living bacteria may play an important and previously overlooked role in facilitating species coexistence among primary consumers at hydrothermal vents and other chemosynthesis-based ecosystems.

Keywords: hydrothermal vent, gastropod, bacteria, carbon-fixation pathway, food web

\section{INTRODUCTION}

While a number of spatially-dominant species in hydrothermal vent communities have symbiotic relationships with chemoautotrophic bacteria, the majority of endemic vent metazoans are consumers that apparently do not feed on symbiont-containing megafauna (Fisher et al., 1994; Bergquist et al., 2007; De Busserolles et al., 2009). Most vent invertebrates are grazers and deposit feeders that consume free-living microbes, protists, and other small invertebrates (Van Dover and Fry, 1994; Levesque et al., 2005; Limen 
et al., 2007). A few specific trophic relationships have been identified among protists (Sauvadet et al., 2010), meiofauna (Limen et al., 2007, 2008), and macrofauna (e.g., Fisher et al., 1994; Sancho et al., 2005; Voight, 2005; Bergquist et al., 2007; Voight and Sigwart, 2007; DeBusserolles et al., 2009), but the vast majority of the relationships are undefined at the base of the food web.

Although chemosynthetic primary producers are found in the subsurface biosphere on and near the seafloor, in the vent effluent, and in the hydrothermal plume, metazoan consumers are more or less confined to the seafloor and overlying water column (Govenar, 2012). Within this smaller range of vent habitats, many studies have identified two or more isotopically distinct microbial food sources for consumers (e.g., Van Dover and Fry, 1994), but surprisingly little is known about which chemosynthetic microbes are consumed. In a survey of lipid profiles from different consumers from diffuse-flow vents at the East Pacific Rise, bacteria appeared to be the primary food source (Phleger et al., 2005a, b). However, neither functional nor phylogenetic groups of bacteria could be distinguished, and the neither the consumption of archaea nor archaeal lipids could be confirmed (Thurber et al., 2013). Archaea may be consumed where they are more prevalent, such as high-temperature chimneys and vents with high methane concentrations, where there is a higher incidence of methanogens (Takai et al., 2006,;Thurber et al., 2013). Heterotrophic bacteria, abiotic organics, and photosynthetic detritus can also be important sources of organic carbon in areas of lower hydrothermal fluid flux (Tunnicliffe et al., 2003; Levesque et al., 2005; Limen et al., 2008).

Gastropods are the most abundant and diverse grazers at deep-sea hydrothermal vents (Desbruyères et al., 2006) and could play an important role in structuring vent communities and the flow of energy through top-down processes that regulate primary production and metazoan recruitment. Over 94,000 Depressigyra globulus individuals and 33,800 Lepetodrilus fucensis were recovered from a single aggregation of the tubeworm Ridgiea piscesae (Bergquist et al., 2007), and >38,900 individuals representing 13 different gastropod species were collected with a single aggregation of the tubeworm Riftia pachyptila (Govenar et al., 2005). Some gastropod species are widely distributed among different hydrothermal vent habitats, and others occur in specific microhabitats, in association with particular 
foundation species, or during some stages of succession (Van Dover, 2002; Mullineaux et al., 2003;

Govenar et al., 2005; Mills et al., 2007). Experiments have demonstrated that some vent-endemic gastropods are capable of actively seeking warmer temperatures, presumably to take advantage of greater food availability (Bates, 2005). Other species occupy cooler habitats (Bates, 2005; Mills et al., 2007) in response to abiotic or biogenic cues or to avoid predators in warmer zones (Mills et al., 2007). While morphological evidence, microscopic analysis of stomach contents, stable isotopes, and lipid profiles of gastropods suggest that gastropods feed primarily on free-living bacteria (e.g., Fretter, 1988, 1990; Fisher et al., 1994; Phleger et al., 2005), the results of manipulative field experiments suggest that some of the same gastropod species may also be grazing on invertebrate recruits and substantially altering macrofaunal community structure (Micheli et al., 2002; Mullineaux et al., 2003). In addition to the ecological implications of consuming either primary producers or invertebrate recruits, differences in the diets of co-occurring species may contribute to the high abundance and diversity of vent gastropods through niche partitioning.

Habitat specialization among co-occurring vent gastropod species may drive differences in their diets, resulting in ecological or evolutionary trade-offs that facilitate species coexistence. For example, the patellomorph (limpet) gastropod Lepetodrilus elevatus is numerically dominant nearly everywhere it is sampled (Dreyer et al., 2005; Govenar et al., 2005; Mills et al., 2007), but it occurs in higher relative abundance in areas where there are more concentrated hydrothermal fluids (Mills et al., 2007). A congener, L. ovalis occurs with L. elevatus nearly everywhere where it is sampled (Dreyer et al., 2005; Govenar et al., 2005; Mills et al. 2007), but it is relatively more abundant in areas where there are less concentrated hydrothermal fluids. Thus, gastropods (e.g., L. elevatus) may benefit from greater access to high productivity by chemosynthetic primary producers in warmer vent microhabitats, but may also suffer energetic costs resulting from physiological adaptations to extreme or variable temperatures, reduced chemical concentrations, and oxygen availability. Gastropods that either do not have these adaptations or select cooler habitats for other reasons (Mills et al., 2007) may feed in less productive habitats where different groups of bacteria occur. Therefore, the differences in diet stemming from habitat specialization 
may facilitate species coexistence in heterogeneous vent habitats and contribute to the wide distribution, high abundance, and high diversity of gastropods in hydrothermal vent communities.

To examine the variability of the diet among gastropod grazers at the East Pacific Rise and to investigate the role of trophic dynamics in structuring vent communities, we compared the tissue carbon and nitrogen stable isotope values from multiple individuals of five different species of patellomorph gastropods collected at five diffuse-flow vent sites on the East Pacific Rise (EPR) in 2002 and 2006. We also examined unique 16S rRNA sequences (haplotypes) from the stomach contents of a subset of these gastropods collected in 2006 to identify their bacterial food sources and link specific microorganisms to the stable isotopic composition of the consumer.

\section{METHODS}

Five species of gastropods were collected with the DSV Alvin from five diffuse-flow hydrothermal vent sites near $9^{\circ} 50^{\prime} \mathrm{N}$ on the East Pacific Rise (Table 1). In 2002, gastropods were collected from four diffuse-flow vent sites, either with intact aggregations of Riftia pachyptila, using the Bushmaster Jr. (as described in Govenar et al., 2005) or with scoops of Bathymodiolus thermophilus. In association with the gastropods sampled for this study, Le Bris et al. (2006) characterized the temperature and chemistry of diffuse-flow fluids of the four sites ("Tica", "Riftia Field", "Mussel Bed", and "Biovent"), and Governar et al. (2005) characterized the composition of the epifaunal community associated with the aggregations of R. pachyptila at Tica and Riftia Field (summarized in Table 2). Although collected by a different group of researchers, the community associated with $B$. thermophilus was sampled at Mussel Bed and Biovent in 2001; Dryer et al. (2005) characterized this community, which provided a valuable comparison to our samples (Table 2). In 2006, gastropods were collected with a slurp sampler from a fifth diffuse-flow vent site, "Marker 7" $\left(9^{\circ} 47.26^{\prime} \mathrm{S}, 104^{\circ} 16.98^{\prime} \mathrm{W}\right)$, which had been spared by the 2005-06 seafloor eruption in the same area. At the time of sampling, Bathymodiolus thermophilus mussels visually dominated the megafaunal community, overgrowing many of the remaining individuals of $R$. pachyptila at the site. 
to the ship and then transferred to either 70 or $95 \%$ ethanol for storage and shipping to home laboratories. Then, individuals collected in 2002 were removed from their shell, dried at $60^{\circ} \mathrm{C}$, and pulverized for carbon and nitrogen stable isotope analysis at the Stable Isotope Laboratory of the Ecosystems Center, Marine Biological Laboratory. After shipping to Woods Hole Oceanographic Institution (WHOI), the gastropods collected in 2006 were dissected following ethanol-flame sterilization techniques, and both the dissected stomachs and a sample of the mantle were placed immediately into separate tubes containing ATL buffer for DNA extraction with the DNEasy Blood and Tissue kit (QIAGEN, following the manufacturer's instructions). Stomachs were easily identified in the visceral cap after removing the shell and remained intact until placed into the buffer. DNA was also extracted, following the same procedures, from the mantle and from a sample of cyanobacteria for negative and positive controls, respectively. PCR was used to amplify the entire $16 \mathrm{~S}$ rRNA gene (1540 bp) in DNA obtained from the dissected stomachs and the controls, with universal bacterial primers (EUB1-EUB2, Ward et al., 2000). Amplicons were then purified with the QIAquick PCR purification kit (QIAGEN) and cloned with the TOPO-TA cloning kit (Invitrogen). DNA sequencing with M13-forward and M14-reverse primers was then used in one-eighth format sequencing reactions using Big Dye terminators (version 3, Perkin-Elmer) in 96-well plates and purified by isopropanol precipitation before sequencing on an ABI 3730XL capillary sequencer at The Josephine Bay Paul Center, Marine Biological Laboratory. The remains of these animals were then processed for stable isotope analysis as described above.

Carbon and nitrogen stable isotope values were tested for normal distribution, and ANOVA was used to determine significant differences among sites and among species. Pairwise comparisons of sites and species were evaluated with the Tukey Kramer test. 16S rRNA sequences obtained from the clone libraries isolated from the stomachs of each of the four gastropod species were aligned and manually edited in Clustal X. The resulting aligned clean sequences were compared in a Kimura-2 distance matrix in Mega v. 6.06 to determine unique 16S rRNA sequences. Each unique sequence was individually referenced against the Greengenes database via BLAST (blastn) to determine taxonomic identity or 
association. For a first-order determination of phylogenetic placement, few sequences could be assembled into full-length 16S rRNA reads (perhaps due to DNA degradation in the stomach) and thus, sequences of 505- 650 bp obtained with the M13-forward primer were used in phylogenetic analysis.

134 Given this shorter sequence length, we conservatively limited phylogenetic assignment to the class taxonomic level, utilizing neighbor-joining trees (with 500 bootstrap replications) in Mega for comparisons of the obtained sequences to environmental samples from hydrothermal vents at the EPR..

\section{RESULTS}

Tissue stable isotope values of the five gastropod species collected among five diffuse-flow vent sites on the East Pacific Rise ranged from -24.3 to $-8.1 \%$ for $\delta^{13} \mathrm{C}$ and from 3.5 to $8.6 \%$ for $\delta^{15} \mathrm{~N}$ (Fig. and among sites $(\mathrm{F}=9.21, \mathrm{df}=4, \mathrm{p}<0.001)$, but nitrogen stable isotope values were only significantly different among sites $(\mathrm{F}=2.86, \mathrm{p}=0.034)$. In post-hoc comparisons, the $\delta^{13} \mathrm{C}$ values were most enriched in ${ }^{13} \mathrm{C}$ (heaviest) at Tica (mean $=-10.4 \%$ ); and the $\delta^{13} \mathrm{C}$ values were the least enriched in ${ }^{13} \mathrm{C}$ (lightest) at Biovent $($ mean $=-17.7 \%$ ) and Mussel Bed $($ mean $=-17.8 \%$ ). Carbon stable isotope values at Riftia Field (mean $=-13.7 \%$ ) were not significantly different from Tica, and $\delta^{13} \mathrm{C}$ values from Marker 7 (mean $=-16.4 \%$ ) were not significantly different from Riftia Field, Biovent, or Mussel Bed. Nitrogen stable isotope values were significantly more enriched in ${ }^{15} \mathrm{~N}$ at Mussel Bed (mean $=7.61 \%$ ) and less enriched at Riftia Field (mean $=6.11 \%$ ), but the range of these values was so small $(1.5 \%)$ that the differences in $\delta^{15} \mathrm{~N}$ values may not represent meaningful differences in dietary sources of nitrogen.

At Tica, neither the $\delta^{13} \mathrm{C}$ values (-11.1 to $-9.8 \%$ ) nor the $\delta^{15} \mathrm{~N}$ values (7.1 to $8.0 \%$ ) were significantly different among the three sampled gastropod species, Lepetodrilus elevatus, L. pustulosus, and Rhyncopelta concentrica (Fig. 2A). At Riftia Field, Biovent, and Mussel Bed, there were significant differences among the $\delta^{13} \mathrm{C}$ values of the sampled gastropod species $\left(\mathrm{F}_{\mathrm{RF}}=8.54\right.$, df $=3, \mathrm{p}=0.007 ; \mathrm{F}_{\mathrm{BV}}=$ 
among the carbon and nitrogen stable isotope values $\left(\delta^{13} \mathrm{C}: \mathrm{F}_{\mathrm{M} 7}=51.91, \mathrm{df}=3, \mathrm{p}<0.001 ; \delta^{15} \mathrm{~N}: \mathrm{F}_{\mathrm{M} 7}=\right.$ 9.87, $\mathrm{df}=3, \mathrm{p}=0.007$ ) (Fig. 2B-E). More specifically, at Riftia Field, the carbon stable isotope values of L. elevatus were most enriched in ${ }^{13} \mathrm{C}$ (mean $=-10.6 \%$ ), and L. pustulosus had the least enriched values $\left(\right.$ mean $=-17.0 \%$ o). R. concentrica and L. ovalis had intermediate $\delta^{13} \mathrm{C}$ values (mean $=-13.1$ and $-14.0 \%$, respectively), which were not significantly different from either L. elevatus or L. pustulosus. At Biovent and Mussel Bed, the carbon stable isotope values of L. elevatus were also the most enriched in ${ }^{13} \mathrm{C}$ (mean $=-13.6$ and $-13.9 \%$, respectively), but Eulepetopsis vitrea had the least enriched values (mean $=-22.1$ and $-22.5 \%$, respectively). The carbon stable isotope values of $L$. ovalis fell between thsee extremes at both sites (mean $=-17.6 \%$ and $-14.3 \%$, respectively); however at Mussel Bed, the $\delta^{13} \mathrm{C}$ values of $L$. ovalis were not significantly different from L. elevatus.

For the gastropod, Eulepetopsis vitrea, neither the $\delta^{13} \mathrm{C}$ values (-24.4 to $-20.8 \%$ ) nor the $\delta^{15} \mathrm{~N}$ values (4.6 to $7.9 \%$ ) were significantly different among the three sites where it was sampled (Fig. 3A). For L. elevatus and L. ovalis, the carbon stable isotope values differed among sites $\left(\mathrm{F}_{\mathrm{LEL}}=7.64, \mathrm{df}=4, \mathrm{p}\right.$ $\left.=0.004 ; \mathrm{F}_{\mathrm{LOV}}=8.42, \mathrm{df}=2, \mathrm{p}=0.010\right) ;$ and for L. pustulosus and R.concentrica, both the $\delta^{13} \mathrm{C}$ values $\left(\mathrm{F}_{\mathrm{LPU}}=56.25, \mathrm{df}=2, \mathrm{p}<0.001 ; \mathrm{F}_{\mathrm{RCO}}=21.69, \mathrm{df}=1, \mathrm{p}=0.010\right)$ and the $\delta^{15} \mathrm{~N}$ values $\left(\mathrm{F}_{\mathrm{LPU}}=10.41, \mathrm{df}=2\right.$, $\left.\mathrm{p}=0.011 ; \mathrm{F}_{\mathrm{RCO}}=15.28, \mathrm{df}=1, \mathrm{p}=0.017\right)$ were significantly different among sites (Fig. 3B-E). More specifically, L. elevatus had $\delta^{13} \mathrm{C}$ values that were significantly more enriched in ${ }^{13} \mathrm{C}$ at Tica and Riftia Field (-10.3 and $-10.5 \%$, respectively) and the least enriched at Marker $7\left(-15.2 \%\right.$ ), but $\delta^{13} \mathrm{C}$ values from Biovent and Mussel Bed (-13.6 and -13.9\%o, respectively) were not significantly different from either Tica and Riftia Field or Marker 7. For L. pustulosus, the most enriched $\delta^{13} \mathrm{C}$ values were also from Tica (-9.8 \%), followed by Marker 7 (-14.2\%o), and then Riftia Field (-17.0 \%o). Similarly, the most enriched $\delta^{15} \mathrm{~N}$ values were from Tica and Marker 7 (7.3 and 8.2\%, respectively), and the least enriched values were at Riftia Field (4.9\%). For $R$. concentrica, both the carbon and the nitrogen stable isotope values were more enriched at Tica (mean $\delta^{13} \mathrm{C}=-11.1 \%$, mean $\delta^{15} \mathrm{~N}=8.0 \%$ ) than at Riftia Field (mean $\delta^{13} \mathrm{C}=-13.2 \%$, mean $\delta^{15} \mathrm{~N}=6.8 \%$ ). In contrast, for L. ovalis, the most enriched values were from 
Mussel Bed and Riftia Field (-14.3 and -14.0\%, respectively), and the least enriched were from Marker 7 and Biovent (-17.1 and -17.6\%o, respectively).

For the gastropods from Marker 7, unique16S rRNA sequences from their stomach contents were analyzed and compared to their stable isotope composition. All four gastropod species hosted unique sequences belonging to the epsilon-proteobacteria in their stomach contents. Specifically, of the 60 and 80 clones obtained from the stomach contents of L. elevatus and L. pustulosus, respectively, all of the unique sequences were epsilon-proteobacteria (Table 3). Of the 60 and 114 clones obtained from the stomach contents of L. ovalis and E. vitrea, respectively, each had one unique sequence that belonged to the deltaproteobacteria. However, only E. vitrea had unique sequences that belonged to the alpha-proteobacteria, green non-sulfur bacteria (chloroflexi), and planctomycetes (Table 3).

Due to the small DNA fragments obtained from some of the stomach content samples, not all of the sequences could be aligned for phylogenetic analysis. For the greatest number of alignable sequences (62\% of total sequences), the samples from the stomach contents clustered with either bacteria associated with the free-living microbial community or with bacterial symbionts of vent macrofauna (Fig. 4). In particular, a large group of epsilon-proteobacteria from the stomach contents of all four gastropod species (Group 1) clustered with samples from high-temperature vent chimneys, a sulfur mat, and the tubes of $R$. pachyptila. Another group of epsilon-proteobacteria (Group 2) from the stomach contents of L. ovalis fell within a different clade that clustered most closely with the epibiont of a congener, L. fucensis, and more broadly with: (1) a sample from the secreted mucus of a the polychaete Paralvinella palmiformis inhabiting vents on the Juan de Fuca Ridge; and (2) the gut epibiont from the shrimp Rimicaris exoculata at the Mid-Atlantic Ridge (MAR). Also within this grouping was a strain of Sulfurimonas autotrophica and a sample from the basalt at the EPR. For the alpha-proteobacteria, some of the sequences (Group 3) clustered with the gut epibiont of $R$. exoculata; and a different, but closely-related group of sequences (Group 4) clustered with samples from the basalt and tubes of $R$. pachyptila at the EPR, as well as methane- and sulfur-metabolizing bacteria from the carbonate chimneys of the Lost City hydrothermal vent field. 


\section{DISCUSSION} expected for endemic hydrothermal vent fauna, which indicates that they all consume food derived from

211 local chemosynthetic primary production. In analyzing the general patterns, gastropods sampled from 212 aggregations of the siboglinid Riftia pachyptila (particularly at Tica) had carbon stable isotope values near $213-11 \%$, and gastropods sampled among dense mussel beds had average carbon stable isotope values that 214 were less enriched in ${ }^{13} \mathrm{C}$. The more enriched $\delta^{13} \mathrm{C}$ values reflect the characteristic carbon stable isotope values of the dominant foundation species (reviewed in Childress and Fisher, 1992 and Cavanaugh et al., 2006) at the time and location of sampling. By combining the carbon stable isotope values and the nitrogen stable isotope values ( $\sim 4$ to $8 \%$ ), there is support for the hypothesis that gastropods feed on recent recruits of these megafaunal species (e.g., Micheli et al., 2002; Mullineaux et al., 2003). The less enriched $\delta^{13} \mathrm{C}$ values may reflect a combination of food sources, which could include both siboglinid tubeworms and the bivalves Bathymodiolus thermophilus and Calyptogena magnifica (all present at Mussel Bed, Biovent, and Marker 7). Alternatively, these gastropods could be non-lethal predators that graze on the exposed tissues - or scavengers that feed on the waste or dead tissues - of the foundation species. Additional work is needed to identify the eukaryotic fraction of the diet for vent gastropods, but the same patterns in the stable isotopic composition could also be driven by the prokaryotic fraction of the diet, investigated here.

The unique 16S rRNA sequences obtained from stomach contents of all four gastropod species were closely related (> 94\% similarity) to environmental samples of free-living bacteria capable of chemoautotrophy, also collected at the EPR. To determine the link between food source and consumer, these sequences from the stomach contents were compared to the stable isotopic composition. The gastropods, Lepetodrilus elevatus and L. pustulosus, which had the most enriched $\delta^{13} \mathrm{C}$ values (-16.0 to -

$231 \quad 13.6 \%$, at Marker 7), had only epsilon-proteobacteria identified in their stomachs; and the gastropod 
species, Eulepetopsis vitrea, which had the least enriched $\delta^{13} \mathrm{C}$ values (-22.1 to $-21.3 \%$, at Marker 7), was the only species that had alpha-proteobacteria in their stomachs. In addition, planctomycetes, and green non-sulfur bacteria were identified in E. vitrea stomachs. While planctomycetes and green nonsulfur bacteria are also members of the free-living microbial community at EPR vents ( $\mathrm{Li}$ et. al., 2008; Mason et al., 2009), both are heterotrophic and thus not expected to substantially influence the carbon stable isotopic signature of the consumer, based on the commonly observed $+/-1 \%$ fractionation from prey to consumer. The fourth gastropod species, L. ovalis, which had stable isotope values that fell between these extremes, had primarily epsilon- but also delta-proteobacteria in their stomachs (Fig. 5). The carbon-fixation pathway of the dominant bacteria in the stomach contents of the four limpet species may account for the variation in the carbon isotope variation of these consumers. All autotrophic epsilon-proteobacteria studied to date convert inorganic carbon into biomass via the reductive tricarboxylic acid (rTCA) cycle rather than the Calvin-Benson-Bassham (CBB) cycle, which is used by most autotrophic gamma- and alpha-proteobacteria (reviewed in Hügler and Sievert, 2011). Isotopic fractionation during carbon fixation via the rTCA cycle is considerably less than via the CBB cycle (Zhang et al., 2002; House et al., 2003). Therefore, when provided the same source of inorganic carbon, microbial biomass produced via the rTCA cycle will be enriched in ${ }^{13} \mathrm{C}$ relative to biomass produced via the CBB cycle (Zhang et al., 2002; House et al. 2003). As observed in the carbon stable isotope values of the consumers, both L. elevatus and L. pustulosus had stomach contents that matched exclusively with epsilon-proteobacteria and enriched $\delta^{13} \mathrm{C}$ isotopic signature, indicative of a diet of bacteria that use the rTCA cycle to fix carbon. In contrast, E. vitrea had stomach contents that matched with alphaproteobacteria and much lower (less enriched) $\delta^{13} \mathrm{C}$, indicative of a diet that uses the CBB cycle to fix carbon. Members of the alpha-proteobacteria are capable of using multiple forms of Rubisco in the CBB cycle and, depending on the form of Rubisco, could produce biomass from the same source of inorganic carbon (Badger and Bek, 2008). However, the limited data available in this study cannot be used to distinguish the form of Rubisco used in the CBB cycle by the alpha-proteobacteria sampled here. 
In addition to free-living bacteria as food sources to these heterotrophs, gastropods at

hydrothermal vents may derive additional nutrition from bacterial symbionts. While Bates (2007) did not find histological evidence of bacterial symbionts in the gills of the lepetodrilid gastropod species analyzed in this study, different bacterial symbionts have been characterized in the gills of peltospirid gastropods in the Southwest Pacific back-arc basis (e.g., Beinart et al., 2012), and there is increasing evidence of the presence, extent, and diversity of gut microbiota in vent animals (e.g., Zbinden et al., 2003; Durand et al., 2010; Corbari et al., 2012). If the bacterial symbioses of vent macrofauna are viewed as a model of digestive or nutritional symbiosis, then in addition to consumed bacteria or products from a resident gut microflora, gut microbes could be ingested either in periods of food scarcity, like in B. thermophilus (Fisher et al., 1988), or as part of the life cycle of the gut microbes themselves, like in R. pachyptila (Bright et al., 2000). The samples presented here are a small subset of the greater diversity of microbes in the guts of these gastropods, and the wider diversity in the gut microbiome of vent animals. Further investigation of the gut microbiota in vent gastropods and the interaction between resident and transient bacteria in the gut is needed to more fully understand the contribution of bacteria to the base of the food web at hydrothermal vents.

Patterns in the stable isotope values and stomach contents generally reflect the microhabitat conditions in which these four gastropod species typically occur. The gastropods L.elevatus and L.pustulosus are most often associated with higher hydrothermal fluid flux in diffuse-flow habitats (Dreyer et al., 2005; Govenar et al., 2005; Mills et al. 2007), where there is likely to be a higher relative abundance of epsilon-proteobacteria (Campbell et al., 2006). In addition, our results indicate that $E$. vitrea, common in habitats with lower hydrothermal fluid flux (Dreyer et al., 2005; Govenar et al., 2005; Mills et al., 2007), has apparently no dietary overlap with Lepetodrilus spp.

By identifying the variation in food sources consumed by hydrothermal vent grazers, these results also provide a mechanistic explanation for the patterns observed in other chemosynthesis-based ecosystems. The carbon stable isotope values of consumers from the Mid-Atlantic Ridge fell into two groups that corresponded to either more enriched $\delta^{13} \mathrm{C}$ values in warmer habitats or less enriched $\delta^{13} \mathrm{C}$ 
values in cooler habitats (De Busserolles et al., 2009). Similarly, carbon stable isotope values of

284 consumers at active vents had more enriched $\delta^{13} \mathrm{C}$ values than at inactive vents (Levin et al., 2009).

285 While these studies did not identify the food sources, our results provide direct evidence to support the

286 same conclusion that consumers in the warmer habitats feed on epsilon-proteobacteria that use the rTCA

287 cycle and are likely to dominate in this habitat, while in the cooler habitats they feed on other bacteria that 288 use the CBB cycle.

Our results also provide evidence that habitat specialization may lead to niche partitioning among grazers at hydrothermal vents, as demonstrated for deposit-feeding polychaetes at Juan de Fuca Ridge (Leveseque et al., 2003). At three diffuse-flow vent sites, the gastropod E. vitrea had the same trophic position and bacterial stomach contents that were remarkably different than other co-occurring gastropod species. While it is unlikely that E. vitrea is selecting specific microbes to consume, the patterns support the hypothesis that this species is a specialist to particular microhabitat or ecological niche (Mills et al., 2007). In further comparisons of stable isotope signatures and stomach content composition to the relative abundance of the gastropods at different vent sites, there is also some indication of niche partitioning among congeners of the genus Lepetodrilus. At Tica, where sulfide concentrations were the highest (Table 2), productivity by sulfur-oxidizing chemoautotrophic bacteria may have also been the greatest among the five vent sites in this study. The greater productivity may have consequently led to greater food availability (particularly of epsilon-proteobacteria) and subsequently to high abundances (Table 2) and shared food sources among co-occurring gastropods (Fig. 2A). However, with lower sulfide concentrations at Mussel Bed and Biovent, food availability may have been more limited. As a result, conditions at Mussel Bed may have led to competition between L. elevatus and L. ovalis, which appear to have the same food source (this study) and similar relative abundance. Conversely, conditions at Biovent may have either favored L. elevatus, which had the same food source as at Mussel Bed but much higher relative abundance, and/or disadvantaged $L$. ovalis, which had a different food source than at 307 Mussel Bed and a much lower relative abundance. There were no quantitative samples of the gastropod community to evaluate the relative abundance among species, but L. elevatus and L. ovalis also appear to 
have overlapping but distinct food sources at Marker 7, like at Biovent. At Riftia Field, where the sulfide

310 concentrations were the lowest among the five sites but the iron concentrations were quite high (Table 2),

311 there is the greatest variability in food sources (largest range in $\delta^{13} \mathrm{C}$ values) among the species of

312 Lepetodrilus. Habitat specialization and niche partitioning of available free-living bacteria may further

313 contribute to the high abundance and diversity of gastropods.

314 The phylogenetic and metabolic diversity of free-living bacteria among spatially heterogeneous

315 habitats in chemosynthesis-based ecosystems may facilitate the coexistence of invertebrate consumers

316 and contribute to the maintenance of local diversity in macrofaunal communities (Van Dover and Fry

317 1994; Govenar, 2012; Levin et al., 2013; Reid et al., 2013). Unlike symbiotic bacteria associated with

318 some vent invertebrates, which are limited to sulfide-, methane- or hydrogen-oxidizers (e.g., Dubilier et

319 al., 2008; Petersen et al., 2011), free-living bacteria are more diverse and can utilize a variety of metabolic

320 pathways (Takai et al., 2006; Hügler and Sievert, 2011). As a result, symbiont-containing invertebrates

321 are limited to specific microhabitats that provide access to chemicals needed to support chemoautotrophy,

322 whereas we demonstrate that heterotrophic consumers feed on range of different free-living bacteria and

323 are thus capable of occupying a wider range of microhabitats. Along the gradient of environmental

324 conditions in hydrothermal vent habitats, competition for shared food sources could further contribute to

325 the regulation of community structure, in the presence of either bottom-up or top-down biological

326 processes (Menge and Sutherland, 1987; Micheli et al., 2002). Furthermore, our results indicate that more

327 than one source of local primary production supports hydrothermal vent food webs, underscoring the

328 range of energy inputs that drive deep-sea chemosynthetic ecosystems. 


\section{ACKNOWLEDGEMENTS}

This work was supported by the National Science Foundation (OCE-0002729 to CRF, OCE-0327261 to TMS, OCE-0937395 to TMS and BG) and by a Deep Ocean Exploration Institute, Woods Hole Oceanographic Institution grant to TMS and a Postdoctoral Fellowship to BG. We thank the captain and crew of the RV Atlantis and the pilots and crew of the DSV Alvin for their expertise and assistance in shipboard and submersible operations on the 2002 (AT 7-26) and 2006 (AT15-13) cruises to the East Pacific Rise. We also thank the Karen Von Damm, chief scientist on the AT15-13 cruise, and the scientific parties of both cruises for their participation in processing the samples at sea. In addition, we are grateful to Ellen Strong, National Museum of Natural History, Smithsonian Institution for her instruction in gastropod anatomy and microsurgical dissection techniques; Leslie Graham, The Josephine Bay Paul Center, Marine Biological Laboratory (MBL), for her assistance with cloning and sequencing; Marshall Otter, The Ecosystems Center, MBL, for processing the stable isotope samples; and to Mark Dennett, Annette Govindarajan, Abigail Fusaro, Walter Cho, and Kate Buckman for assistance in the laboratory. This manuscript was also improved as a result of the comments of two anonymous reviewers. 


\section{REFERENCES}

Bates, A.E., Tunnicliffe, V., Lee, R.W., 2005. Role of thermal conditions in habitat selection by hydrothermal vent gastropods. Marine Ecology Progress Series 305, 1-15.

Bates, A.E., 2007. Feeding strategy, morphological specialisation and presence of bacterial episymbionts in lepetodrilid gastropods from hydrothermal vents. Marine Ecology Progress Series 347: 87-89.

Beinart, R.A., Sanders, J.G., Faure, B., Sylva, S.P., Lee, R.W., Becker, E.L., Gartman, A., Luther III, G.W., Seewald, J.S., Fisher, C.R., Girguis, P.R., 2012. Evidence for the role of endosymbionts in regional-scale habitat partitioning by hydrothermal vent symbioses. Proceedings of the National Academy of Sciences 109 (47): E3241- 3250.

Bergquist, D.C., Eckner, J.T., Urcuyo, I.A., Cordes, E.E., Hourdez, S., Macko, S.A., Fisher, C.R., 2007. Using stable isotopes and quantitative community characteristics to determine a local hydrothermal vent food web. Marine Ecology Progress Series 330: 49-65.

Bright, M., Keckeis, H., Fisher, C.R., 2000. An autoradiographic examination of carbon fixation, transfer and utilization in the Riftia pachyptila symbiosis. Marine Biology 136: 621-632.

Campbell, B.C., Engel, A.S., Porter, M.L., Takai, K., 2006, The versatile epsilon-proteobacteria: key players in sulphidic habitats. Nature Microbiology Reviews 4:458-468.

Cavanaugh, C.M., McKinness, Z.P., Newton, I.L.G., Stewart, F.J., 2006. Marine Chemosynthetic Symbioses. Prokaryotes 1: 475-507.

Childress, J.J., Fisher, C.R., 1992. The biology of hydrothermal vent animals: physiology, biochemistry and autotrophic symbioses. Oceanography and Marine Biology Annual Review 30: 337-441.

Corbari, L., Durand, L., Cambon-Bonavita, M.-A., Gaill, F., Compere. P., 2012. New digestive symbiosis in the hydrothermal vent amphipoda Ventiella sulfuris. Comptes Rendus Biologies 335: 142- 154

De Busserolles, F., Sarrazin, J., Gauthier, O., Gélinas, Y., Fabri, M.C., Sarradin, P.M., Desbruyères, D., 2009. Are spatial variations in the diets of hydrothermal fauna linked to local environmental conditions? Deep-Sea Research II 56: 1649- 1664.

Desburyères, D., Segonzac, M., Bright, M., Eds. 2006. Handbook of Deep-Sea Hydrothermal Vent Fauna, Second completely revised edition. Denisia 18: 544 pp.

Dreyer, J.C., Knick, K.E., Flickinger, W.B., Van Dover, C.L., 2005. Development of macrofaunal community structure in mussel beds on the northern East Pacific Rise. Marine Ecology Progress Series 302: 121-134.

Dubilier, N., Bergin, C., Lott, C., 2008. Symbiotic diversity in marine animals: the art of harnessing chemosynthesis. Nature Review: Microbiology 6: 725- 740.

Durand, L., Zbinden, M., Cueff-Gauchard, V., Duperron, S., Roussel, E.G., Shillito, B., CambonBonavita, M.-A., 2010. Microbial diversity associated with the hydrothermal shrimp Rimicaris exoculata stomach and occurrence of a resident microbial community. FEMS Microbiology Ecology 71: 291-303.

Fisher, C.R., Childress, J.J., Arp, A.J., Brooks, J.M., Distel, D., Favuzzi, J.A., Felbeck, H., Hessler, R., Johnson, K.S., Kennicutt, M.C., Macko, S.A., Newton, A., Powell, M.A., Somero, G.N., Soto, T., 1988, Microhabitat variation in the hydrothermal vent mussel Bathymodiolus thermophilus, at Rose Garden vent on the Galapagos rift. Deep-Sea Research A 35: 1769-1792.

Fisher, C.R., Childress, J.J., Macko, S.A., Brooks, J.M., 1994. Nutritional interactions in Galapagos Rift hydrothermal vent communities: inferences from stable carbon and nitrogen isotope analyses. Marine Ecology Progress Series 103: 45-55. 
Fretter, V.,1988, New archaeogastopod limpets from hydrothermal vents; superfamily Lepetodrilacea II. Anatomy. Philosophical Transactions of the Royal Society B: Biological Sciences 319: 33-82.

Fretter, V.,1990, The anatomy of some new archaeogastropod limpets (Order Patellogastropoda, Suborder Lepetopsina) from hydrothermal vents. Journal of Zoology 222: 592-555.

Govenar, B., Le Bris, N., Gollner, S., Glanville, J., Aperghis, A.B., Hourdez, S., Fisher, C.R., 2005. Epifaunal community structure associated with Riftia pachyptila in chemically different hydrothermal vent habitats. Marine Ecology Progress Series 305: 67-77.

Govenar, B., 2012. Energy transfer through food webs at hydrothermal vents: linking the lithosphere to the biosphere. Oceanography 25(1): 246-255.

House, C.H., Schopft, J.W., Stetter, K.O., 2003. Carbon isotopic fractionation by Archaeans and other thermophilic prokaryotes. Organic Geochemistry 34: 345-356.

Hugler, M., Sievert, S.M., 2011, Beyond the Calvin Cycle: Autotrophic Carbon Fixation in the Ocean. Annual Review Marine Science 3:261-89.

Le Bris, N., Govenar, B., Le Gall, C., Fisher, C.R., 2006. Variability of physico-chemical conditions in 950’N EPR diffuse-flow vent habitats. Marine Chemistry 98: 167- 182.

Levesque, C., Limén, H., Juniper, S.K., 2005. Origin, composition and nutritional quality of particulate matter at deep-sea hydrothermal vents on Axial Volcano, NE Pacific. Marine Ecology Progress Series 289: 43- 52.

Levin, L.A., Ziebis, W., Mendoza, G.F., Betrics, V.J., Washington, T., Gonzalez, J., Thurber, A.R., Ebbe, B., Lee, R.W., 2013. Ecological release and niche partitioning under stress: Lessons from dorvilleid polychaetes in sulfidic sediments at methane seeps. Deep-Sea Research II 92: 214233.

Limén, H., Levesque, C., Juniper, S.K. 2007. POM in macro-/meiofaunal food webs associated with three flow regimes at deep-sea hydrothermal vents on Axial Volcano, Juan de Fuca Ridge. Marine Biology 153: 129- 139.

Limén, H., Stevens, S.J., Bourass, Z., Juniper, S.K., 2008. Trophic ecology of siphonostomatoid copepods at deep-sea hydrothermal vents in the northeast Pacific. Marine Ecology Progress Series 359: 161- 170.

Menge, B.A., Sutherland, J.P., 1987, Community regulation: variation in disturbance, competition, and predation in relation to environmental stress and recruitment. The American Naturalist 130 (5): 730- 757.

Micheli, F., Peterson, C.H., Mullineaux, L.S., Fisher, C.R., Mills, S.W., Sancho, G., Johnson, G.A., Lenihan, H.S., 2002, Predation structures communities at deep-sea hydrothermal vents. Ecological Monographs 72: 365-382.

Mills, S.W., Mullineaux, L.S., Tyler, P.A., 2007. Habitat associations in gastropod species at East Pacific Rise hydrothermal vents (950’N). Biological Bulletin 212: 185-194.

Mullineaux, L.S., Peterson, C.H., Micheli, F., Mills, S.W., 2003. Successional mechanism varies along a gradient in hydrothermal fluid flux at deep-sea vents. Ecological Monographs 73: 523-542.

Petersen, J.M., Zielinski, F.U., Pape, T., Seifert, R., Moraru, C., Amann, F., Hourdez, S., Girguis, P.R., Wankel, S.D., Barbe, V., Pelletier, E., Fink, D., Borowski, C., Bach, W., Dubilier, N., 2011. Hydrogen is an energy source for hydrothermal vent symbioses. Nature 476: 176- 180.

Phleger, C.F., Nelson, M.M., Groce, A.K., Cary, S.C., Coyne, K.J., Nichols, P.D., 2005a. Lipid composition of deep-sea hydrothermal vent tubeworm Riftia pachyptila, crabs Munidopsis 
subsquamosa and Bythograea thermydron, mussels Bathymodiolus sp., and limpets Lepetodrilus spp. Comparative Biochemistry and Physiology, Part B 141: 196- 210.

Phleger, C.F., Nelson, M.M., Groce, A.K., Cary, S.C., Coyne, K.J., Gibson, J.A.E., Nichols, P.D., $2005 b$. Lipid biomarkers of deep-sea hydrothermal vent polychaetes- Alvinella pompejana, A. caudata, Paralvinella grasslei and Hesiolyra bergii. Deep-Sea Research I 52: 2333- 2352.

Reid, W.D.K., C.J. Sweeting, B.D. Wingham, K. Zwiglmaier, J.A. Hawkes, R.A.R. McGill, K. Linse, and N.V.C. Polumin. (2013) Spatial differences in East Scotia Ridge hydrothermal vent food webs: influences on chemistry, microbiology, and predation on trophodynamics. PLOS ONE 8 (6): e65553.

Saudevet, A.-L., Gobet, A., Guillou, L., 2010. Comparative analysis between protist communities from the deep-sea pelagic ecosystem and specific hydrothermal habitats. Environmental Microbiology 12(11): 2946-2964.

Sancho, G., Fisher, C.R., Mills, S., Micheli, F., Johnson, G.A., Lenihan, H.S., Peterson, C.H., Mullineaux, L.S., 2005. Selective predation by the zoarcid fish Thermarces cerebus at hydrothermal vents. Deep-Sea Research I 52: 837- 844.

Soule, S.A., Fornari, D.J., Perfit, M.R., Rubin, K.H., 2007. New insights into mid-ocean ridge volcanic processes from the 2005-2006 eruption of the East Pacific Rise, 9 ${ }^{\circ} 46^{\prime} \mathrm{N}-9^{\circ} 56^{\prime}$ N. Geology 35: 1079- 1082.

Takai, K., Nakagawa, S., Reysenbach, A.-L., Hoek, J., 2006. Microbial ecology of mid-ocean ridges and back-arc basins. In "Back-Arc Spreading Systems: Geological, Biological, Chemical, and Physical Interactions”. American Geophysical Union, Geophysical Monograph Series 166: 185 213.

Thurber, A.R., Levin, L.A., Orphan, V.J., Marlow, J.J., 2012. Archaea in metazoan diets: implications for food webs and biogeochemical cycling. The ISME Journal 6: 1602- 1612.

Tolstoy, M., Cowen, J.P., Baker, E.T., Fornari, D.J., Rubin, K.H., Shank, T.M., Waldhouser, F., Bohnenstiehl, D.R., Forsyth, D.W., Holmes, R.C., Love, B., Perfit, M.R., Weekly, R.T., Soule, S.A., Glazer, B., 2006. A seafloor spreading event captured by seismometers. Science 314: 19201922.

Tunnicliffe, V., Baross, J.A., Gebruk, A., Giere, A.O., Koschinsky, A., Reysenbach, A.L., Shank, T.M., Summit, M., 2003. Group Report: What are the interactions between biotic processes at vents and physical, chemical and geological conditions? In: Halbach, P.E., Tunnicliffe, V., Hein, J.R. (Eds.), Energy and Mass Transfer in Marine Hydrothermal Systems. Dahlem Press, Berlin, pp. 251-270.

Van Dover, C.L., 2002. Community structure of mussel beds at deep-sea hydrothermal vents. Marine Ecology Progress Series 230: 137- 158.

Van Dover, C.L., Fry, B., 1989. Stable isotopic compositions of hydrothermal vent organisms. Marine Biology 102: 257- 263.

Van Dover, C.L., Fry, B. 1994. Microorganisms as food resources at deep-sea hydrothermal vents. Limnology and Oceanography 39 (1): 51-57.

Voight, J., 2005. Hydrothermal vent octopuses of Vulcanoctopus hydrothermalis, feed on bathypelagic amphipods of Halice hesmonectes. Journal of the Marine Biological Association UK 85: 985988.

Voight, J.R., Sigwart, J.D., 2007. Scarred limpets at hydrothermal vents: evidence of predation by deepsea whelks. Marine Biology 152: 129- 133. 
Zbinden, M., Cambon-Bonavita, M.-A., 2006. Occurrence of Deferribacterales and Entomoplasmatales in the deep-sea Alvinocarid shrimp Rimicaris exoculata stomach. FEMS Microbiology Ecology 46: 23-30.

Zhang, C.L., Ye, Q., Reysenbach, A.-L., Gotz, D., Peacock, A., White, D.C., Horita, J., Cole, D.R., Fong, J., Pratt, L., Fang, J., Huang, Y., 2002. Carbon isotopic fractionations associated with thermophilic bacteria Thermatoga maritime and Persephonella marina. Environmental Microbiology 4(1): 58-64. 
Table 1. Collection location of the five gastropod species. All individuals were analyzed for tissue stable isotope content. Samples from Marker 7 (collected in 2006) were also analyzed for bacterial stomach content analysis.

\begin{tabular}{lccccc}
\hline & Tica & Riftia Field & Mussel Bed & Biovent & Marker 7 \\
\hline Eulepetopsis vitrea & & & 3 & 3 & 4 \\
Lepetodrilus elevatus & 3 & 3 & 3 & 3 & 3 \\
Lepetodrilus ovalis & & 3 & 3 & 3 & 2 \\
Lepetodrilus pustulosus & 3 & 3 & & & 3 \\
Rhyncopelta concentrica & 3 & 3 & & \\
\hline
\end{tabular}


Table 2. Date of sampling, visually dominant foundation species, environmental conditions, and relative abundance of five gastropod species, included in this study, at five diffuse-flow hydrothermal vent sites at the East Pacific Rise $\left(9^{\circ} 50^{\prime} \mathrm{N}\right) .<\mathrm{dl}$ indicates that the measured values were below the detection limit; ND indicates that measurements were not taken; and - indicates that quantitative samples were not collected.

*Quantitative samples collected in November 2001.

\begin{tabular}{|c|c|c|c|c|c|}
\hline & Tica & Riftia Field & Mussel Bed & Biovent & Marker 7 \\
\hline Date of sampling & Dec. 2002 & Dec. 2002 & Dec. 2002 & Dec. 2002 & Dec. 2006 \\
\hline Dominant foundation species & Riftia tubeworms & Riftia tubeworms & mussels & Riftia and mussels & Riftia and mussels \\
\hline Max. temperature $\left({ }^{\circ} \mathrm{C}\right)$ & 32 & 54 & 10 & 15 & 12 \\
\hline $\operatorname{Max} . \Sigma \mathrm{H}_{2} \mathrm{~S}\left(\mu \mathrm{mol} \mathrm{kg}{ }^{-1}\right)$ & 283 & 95 & 151 & 156 & 153 \\
\hline Max. $\mathrm{Fe}^{2+}\left(\mu \mathrm{mol} \mathrm{kg}{ }^{-1}\right)$ & $<\mathrm{dl}$ & 65 & $<\mathrm{dl}$ & $<\mathrm{dl}$ & ND \\
\hline $\begin{array}{l}\text { Total Ab. (Rel. Ab.) } \\
\text { of Eulepetopsis vitrea }\end{array}$ & $\begin{array}{c}47 \\
(0.10)\end{array}$ & Abs. & $\begin{array}{c}128^{*} \\
(1.43)\end{array}$ & $\begin{array}{l}36^{*} \\
(0.28)\end{array}$ & - \\
\hline $\begin{array}{l}\text { Total Ab. (Rel. Ab.) } \\
\text { of Lepetodrilus elevatus }\end{array}$ & $\begin{array}{l}22,537 \\
(47.33)\end{array}$ & $\begin{array}{c}2499 \\
(38.18)\end{array}$ & $\begin{array}{c}388^{*} \\
(4.34)\end{array}$ & $\begin{array}{l}4011^{*} \\
(30.92)\end{array}$ & - \\
\hline $\begin{array}{l}\text { Total Ab. (Rel. Ab.) } \\
\text { of Lepetodrilus ovalis }\end{array}$ & $\begin{array}{c}355 \\
(0.75)\end{array}$ & $\begin{array}{c}82 \\
(1.25)\end{array}$ & $\begin{array}{c}385^{*} \\
(4.31)\end{array}$ & $\begin{array}{c}586^{*} \\
(4.52)\end{array}$ & - \\
\hline $\begin{array}{l}\text { Total Ab. (Rel. Ab.) } \\
\text { of Lepetodrilus pustulosus }\end{array}$ & $\begin{array}{c}1222 \\
(2.57)\end{array}$ & $\begin{array}{c}635 \\
(9.70)\end{array}$ & Abs.* & $\begin{array}{c}5^{*} \\
(0.04)\end{array}$ & - \\
\hline $\begin{array}{l}\text { Total Ab. (Rel. Ab.) } \\
\text { of Rhynchopelta concentrica }\end{array}$ & $\begin{array}{l}3679 \\
(7.73)\end{array}$ & $\begin{array}{l}396 \\
(6.05)\end{array}$ & Abs.* & $\begin{array}{c}1^{*} \\
(0.01)\end{array}$ & - \\
\hline References & $\begin{array}{l}\text { Govenar et al. } 2005 \\
\text { Le Bris et al. } 2006\end{array}$ & $\begin{array}{l}\text { Govenar et al. } 2005 \\
\text { Le Bris et al. } 2006\end{array}$ & $\begin{array}{l}\text { Dreyer et al. 2005* } \\
\text { Le Bris et al. } 2006\end{array}$ & $\begin{array}{l}\text { Dreyer et al. 2005* } \\
\text { Le Bris et al. } 2006\end{array}$ & $\begin{array}{l}\text { G.W. Luther III, } \\
\text { unpubl. data }\end{array}$ \\
\hline
\end{tabular}


Table 3. Classification of 16S rRNA sequences in the stomach contents of four species of gastropods collected at Marker 7 on the East Pacific Rise $\left(9^{\circ} 50^{\prime} \mathrm{N}\right)$.

\begin{tabular}{lcccccc}
\hline & $\varepsilon$ & $\delta$ & $\alpha$ & Other & Total clones & $\begin{array}{c}\text { Total } \\
\text { sequences }\end{array}$ \\
\hline Eulepetopsis vitrea $(\mathrm{n}=4)$ & 3 & 1 & 6 & 4 & 114 & 14 \\
Lepetodrilus elevatus $(\mathrm{n}=3)$ & 18 & & & & 60 & 18 \\
Lepetodrilus ovalis $(\mathrm{n}=2)$ & 6 & 1 & & & 35 & 7 \\
Lepetodrilus pustulosus $(\mathrm{n}=3)$ & 6 & & & & 80 & 6 \\
\hline
\end{tabular}




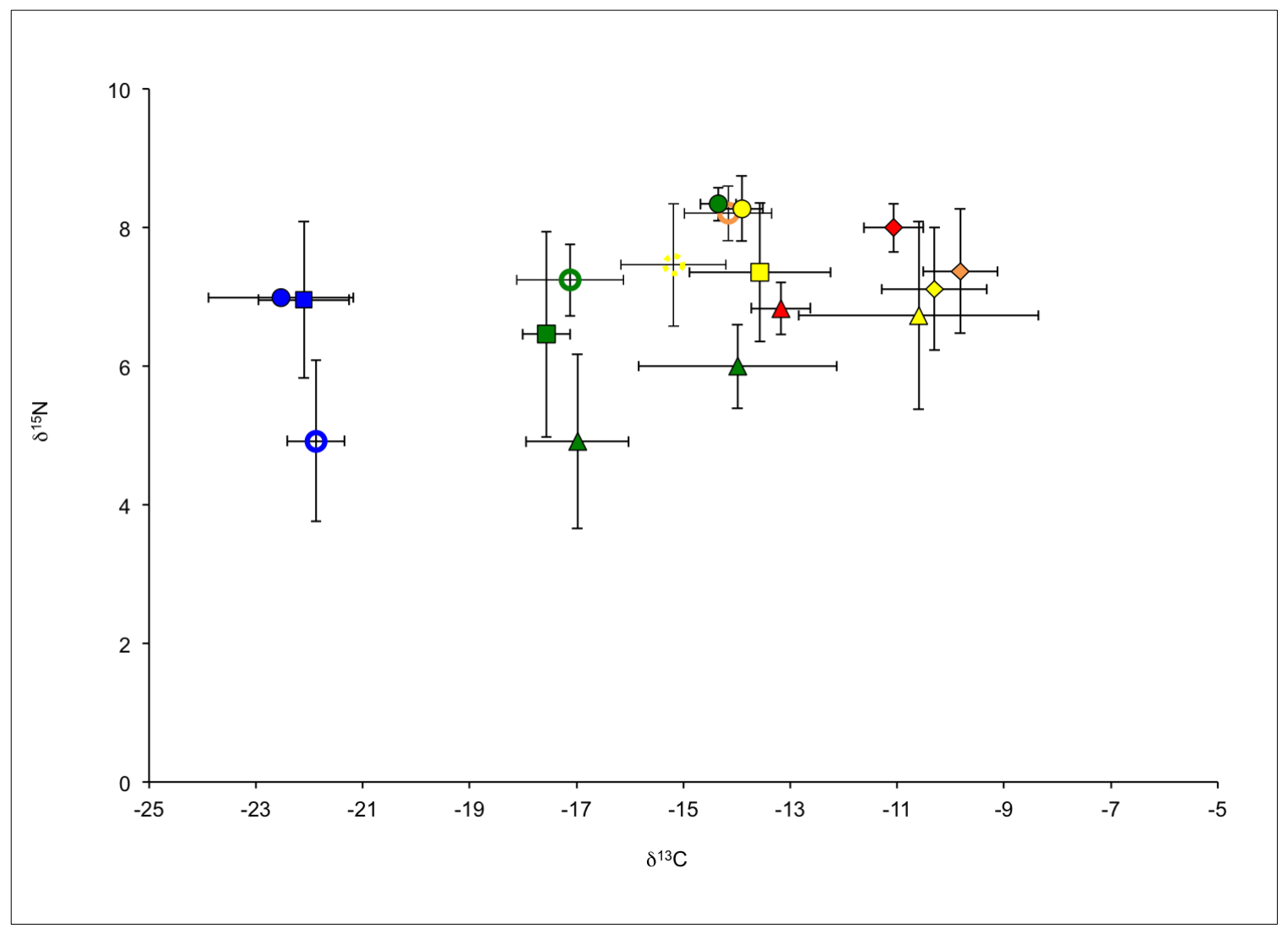

Figure 1. Mean carbon and nitrogen isotope values, with standard deviations, for five gastropod species at five diffuse-flow vent sites on the East Pacific Rise. Gastropod species are differentiated by color: blue $=$ Eulepetopsis vitrea, yellow $=$ Lepetodrilus elevatus, green $=L$. ovalis, orange $=L$. pustulosus, and red $=$ Rhyncopelta concentrica; sites are differentiated by symbols: diamond $=$ Tica, triangle $=$ Riftia Field, solid circle $=$ Mussel Bed, square $=$ Biovent, and open circle $=$ Marker 7 . 

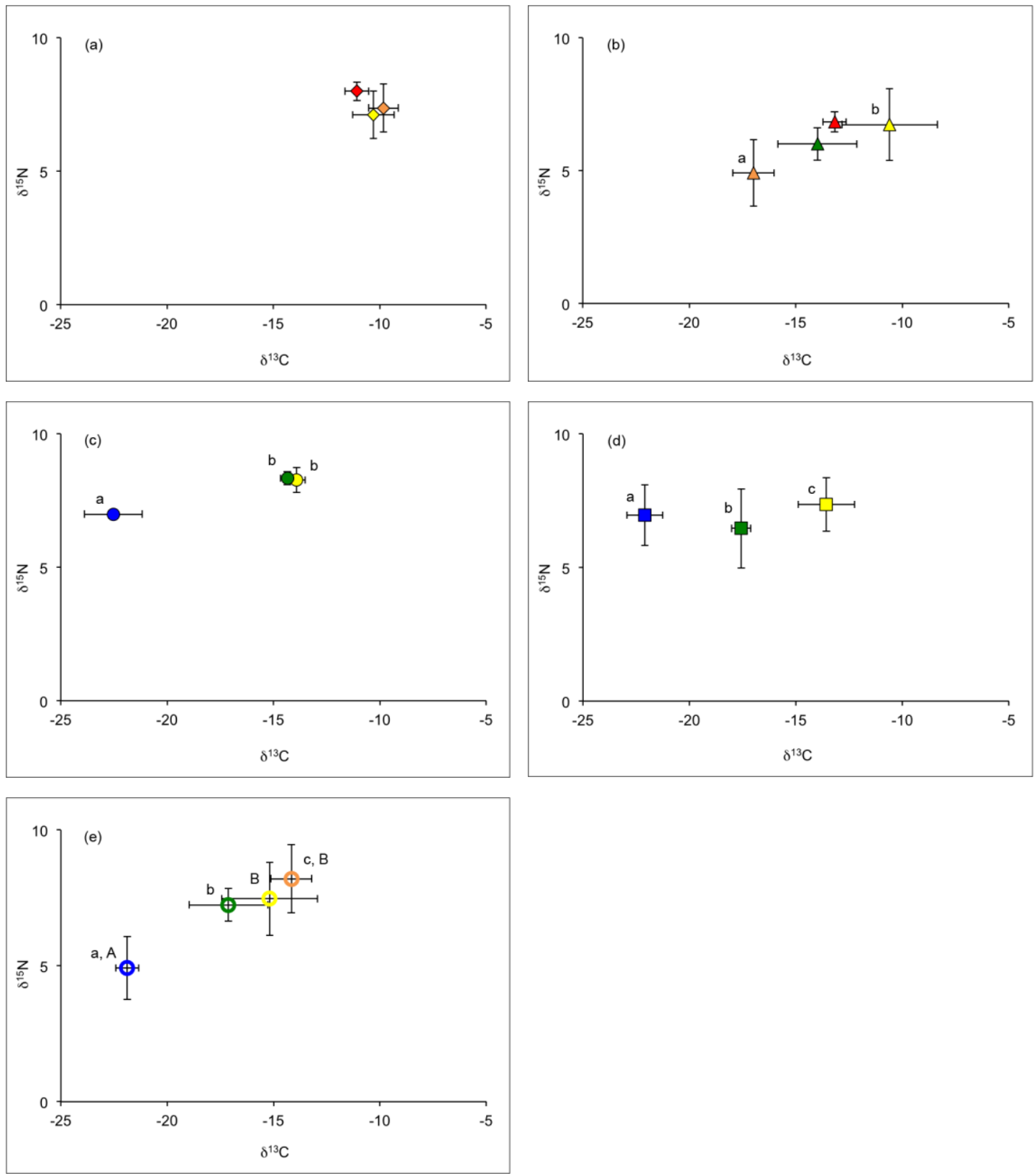

Figure 2A-E. Mean carbon and nitrogen isotope values, with standard deviations, for as many as five gastropod species at five diffuse-flow vent sites (a-e) on the East Pacific Rise. Gastropod species are differentiated by color: blue $=$ Eulepetopsis vitrea, yellow =Lepetodrilus elevatus; green $=$ L. ovalis, orange $=$ Lepetodrilus pustulosus, and red $=$ Rhyncopelta concentrica $;$ and sites are differentiated by symbols: diamond $=$ Tica $(a)$, triangle $=$ Riftia Field (b), closed circle $=$ Mussel Bed (c), square $=$ Biovent (d), and open circle $=$ Marker 7 (e). Results of pairwise posthoc comparisons are represented by lowercase letters that indicate, significantly different $\delta^{13} \mathrm{C}$ values, and uppercase letters that indicate significantly different $\delta^{15} \mathrm{~N}$ values. 

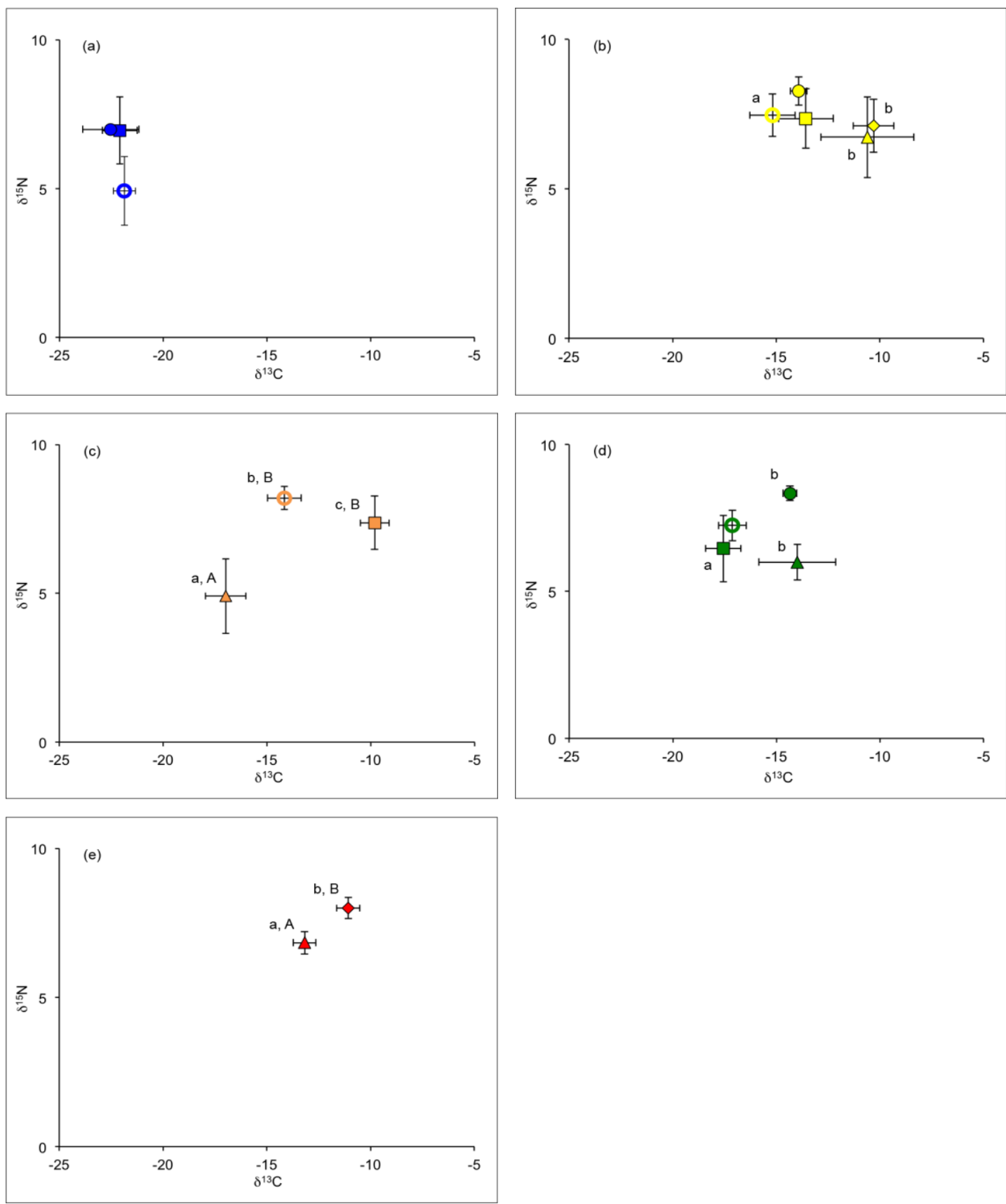

Figure 3A-E. Mean carbon and nitrogen isotope values, with standard deviations, for as many as five gastropod species (a-e) at five diffuse-flow vent sites on the East Pacific Rise. Gastropod species are differentiated by color: blue $=$ Eulepetopsis vitrea $(\mathrm{a})$, yellow $=$ Lepetodrilus elevatus (b), green $=$ L. ovalis $(\mathrm{c})$, orange $=L$. pustulosus $(\mathrm{d})$, and red $=$ Rhyncopelta concentrica $(\mathrm{e})$; and sites are differentiated by symbols: diamond $=$ Tica, triangle $=$ Rifti Field, closed circle $=$ Mussel Bed, square $=$ Biovent, and open circle $=$ Marker 7 . Results of pairwise post-hoc comparisons are represented by lowercase letters that indicate, significantly different $\delta^{13} \mathrm{C}$ values, and uppercase letters that indicate significantly different $\delta^{15} \mathrm{~N}$ values. 


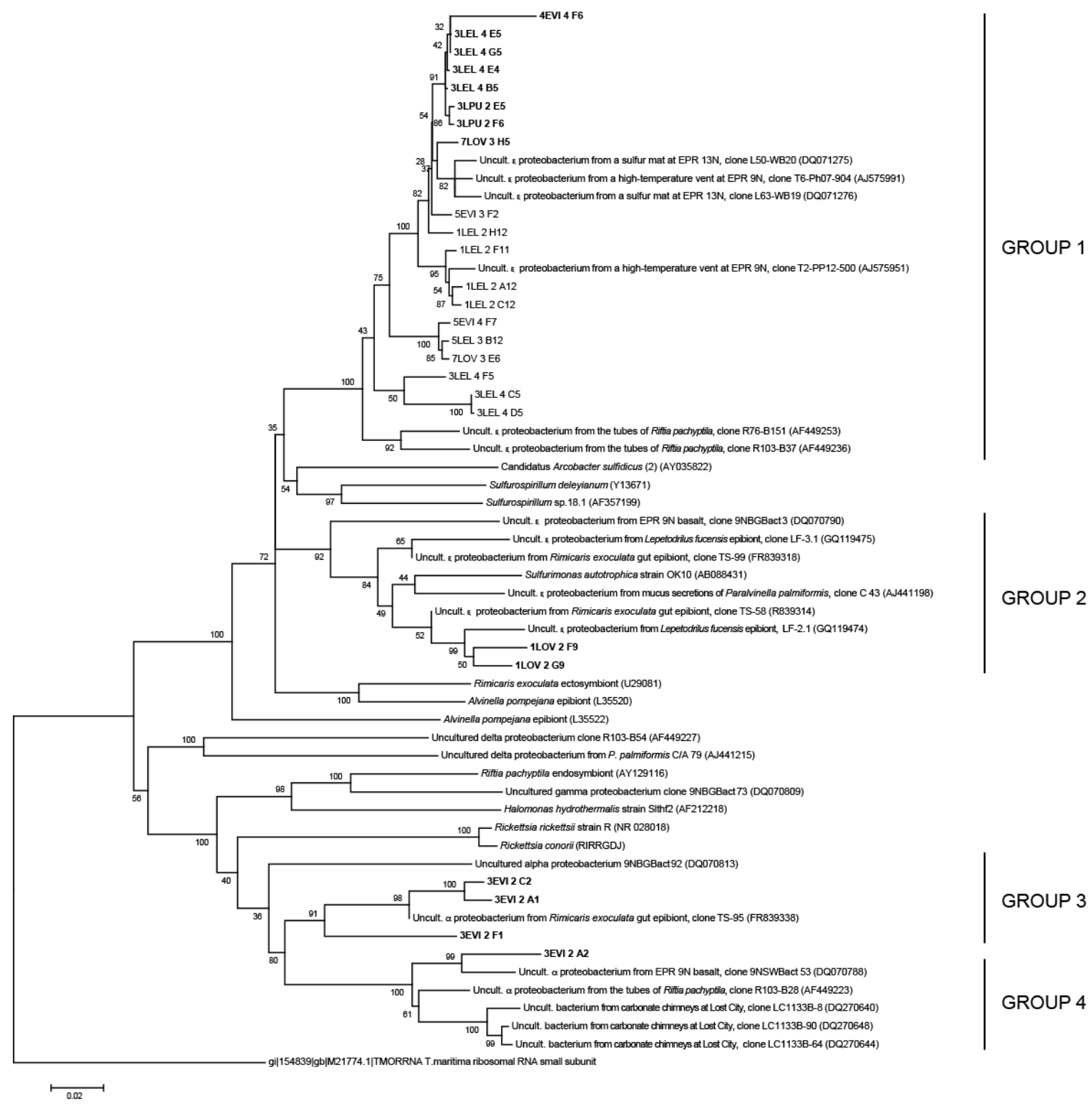

Figure 4. Neighbor-joining phylogenetic tree of $16 \mathrm{~S}$ rRNA sequences from four species of gastropods from Marker 7 on the East Pacific Rise. New unique sequences generated herein are named according to the individual (first number), the species (following a three-letter code for the first letter of the genus and first two letters of the species), the amplicon (second number), and the clone (last letter and number). Groups 1- 4 identify relationships between sequences obtained from gastropod stomach contents to environmental samples from hydrothermal vents. Bootstrap values from 500 iterations. The scale bar indicates 0.02 nucleotide substitutions per site. 


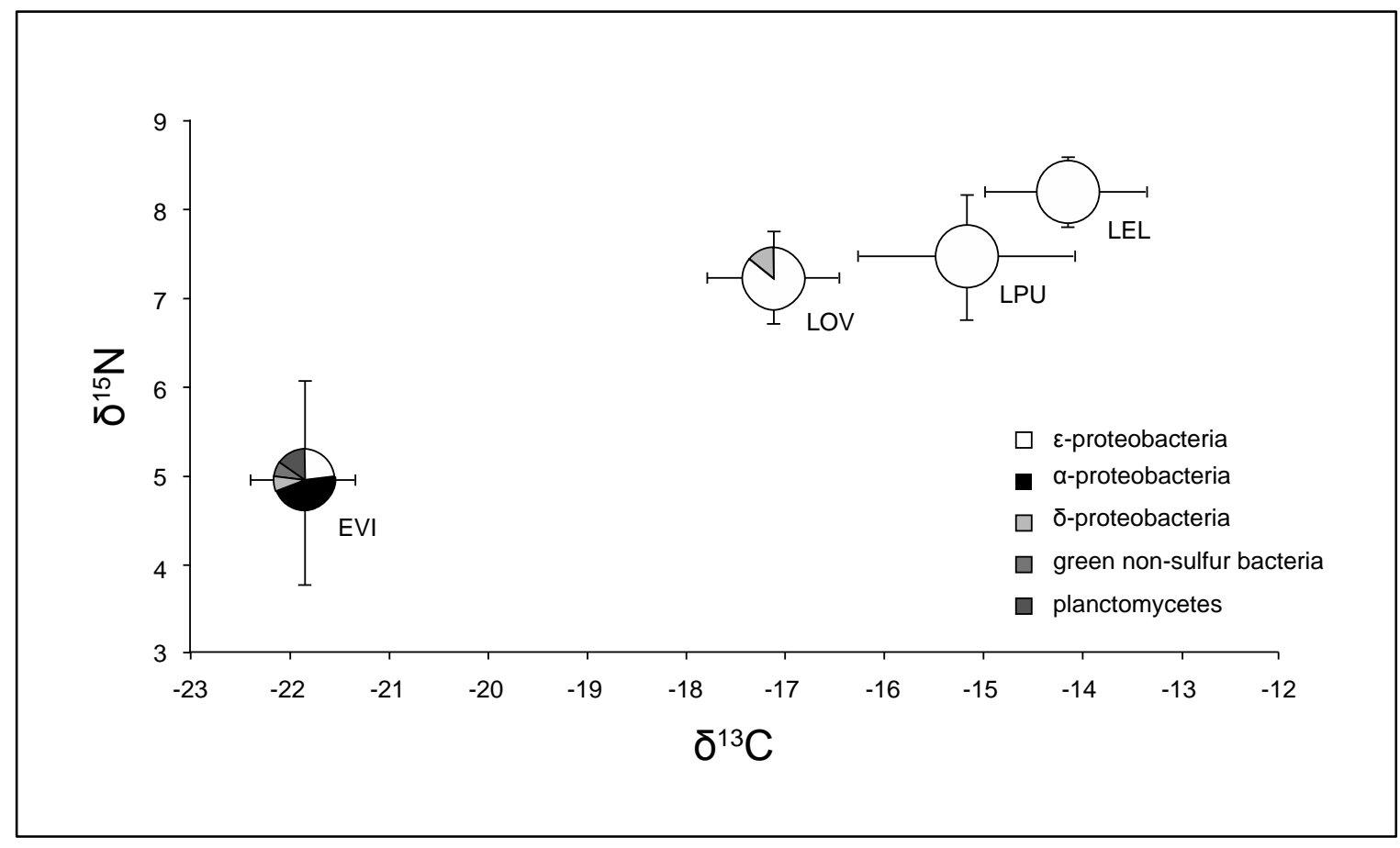

Figure 5. Average carbon and nitrogen stable isotope values, with standard deviations, with relative abundance of different bacterial groups identified in the stomach contents of four species of gastropod limpets, Eulepetopsis vitrea (EVI), Lepetodrilus ovalis (LOV), L. pustulosus (LPU), and L. elevatus (LEL) at Marker 7. 